\title{
UPAYA PERBAIKAN KINERJA SUMBER DAYA MANUSIA DALAM PENINGKATAN PELAYANAN KAPAL PADA PT. ANSARI SHIPPING BATAM
}

\author{
${ }^{1}$ Yusnidah , ${ }^{2}$ Muhammad Fazalurrahman \\ ${ }^{1}$ TEKNIKA ${ }^{, 2}$ KPNK, Politeknik Adiguna Maritim Medan \\ email: asdayusnidah@gmail.com
}

\begin{abstract}
Abstrak. Perusahaan PT. Ansari Shipping Batam merupakan perusahaan pelayaran yang bergerak dibidang pelayanan keagenan kapal termasuk stevedoring dan cargodoring, beserta freight forwarding dan custom clarance yang beroperasi sekitar wilayah Batam. di PT. Ansari Shipping Batam dalam melaksanakan tugas masing-masing seluruh karyawan diharapkan bekerja sesuai dengan visi dan misi dalam strategi perusahaan, dengan visi terwujudnya pelayanan yang prima "customer satisfaction" kepada pengguna jasa, dan dengan misi mengusahakan pelayanan tepat waktu guna memperkecil komplain dari pengguna jasa dan mengoptimalkan estimasi kepada pengguna jasa. Dengan jabatan yang rangkap sehingga dapat menimbulkan penurunan kinerja sumber daya manusia, oleh karena itu untuk tidak terjadi jabatan yang rangkap sehingga diperlukan perbaikan dengan penambahan karyawan sehingga dapat meningkatkan sumber daya manusia yang ada pada Perusahaan PT. Ansari Shipping Batam. Dalam setiap memberikan pelayanan sumber daya manusia selalu memberikan pelayanan sebaik mungkin, dan tepat waktu kepada para pelanggan atau pengguna jasa. Dalam setiap kegiatan di perusahaan PT. Ansari Shipping Batam, perusahaan mempunyai peran yang sangat penting khususnya pada setiap perencanaan kegiatan, dalam masingmasing tugasnya sumber daya manusia selalu dituntut dalam setiap melakukan kegiatan atau tugas masing-masing supaya dalam melaksanakan tugas tidak menimbulkan kerugian.
\end{abstract}

Kata Kunci: Kinerja,Sumber Daya Manusia,PT.Ansari Shipping Batam

\begin{abstract}
Company PT. Ansari Shipping Batam is a shipping company engaged in ship agency services including stevedoring and cargodoring, along with freight forwarding and custom clarance operating around the Batam area. at PT. Ansari Shipping Batam in carrying out their respective duties, all employees are expected to work in accordance with the vision and mission in the company's strategy, with the vision of realizing excellent service "customer satisfaction" to service users, and with the mission of seeking timely service to minimize complaints from service users and optimizing estimates for service users. With multiple positions so that it can cause a decrease in the performance of human resources, therefore there is no need for duplicate positions so that improvements are needed by adding employees so that they can increase existing human resources at PT. Ansari Shipping Batam. In each providing services, human resources always provide the best possible service, and on time to customers or service users.In every activity in the company PT. Ansari Shipping Batam, the company has a very important role, especially in every planning to In each of their duties, human resources are always
\end{abstract}


required to carry out their respective activities or tasks so that in carrying out their duties they do not cause losses.

Keywords: Crew Foreign, Imigrasi, PT.Eka Nusantara Cabang Belawan

\section{PENDAHULUAN}

Dalam setiap perusahaan, potensi sumber daya manusia pada hakekatnya merupakan salah satu modal utama dan memegang peranan penting untuk mencapai tujuan organisasi dari suatu perusahaan. Oleh karena itu perusahaan perlu mengelola sumber daya manusia sebaik mungkin. Sebab itu merupakan kunci keberhasilan pada suatu perusahaan dalam pencapian tujuan perusahaan.

Sumber Daya Manusia adalah salah satu faktor yang sangat penting bahkan tidak dapat dilepaskaan dari sebuah organisasi, baik institusi maupun perusahaan, dan juga merupakan kunci yang menentukan terhadap perkembangan perusahaan. Pada hakekatnya sumber daya manusia adalah himpunan atau kelompok manusia-manusia yang dipekerjakan disebuah organisasi sebagai penggerak untuk mencapai tujuan organisasi. Pada saat ini karyawan bukan lagi sebagai sumber daya belaka melainkan lebih merupakan modal atau aset bagi perusahaan.

Secara garis besar sumber daya manusia dapat lebih diartikan sebagai individu yang berperan sebagai penggerak utama dalam perusahaan dan berfungsi sebagai aset yang harus dilatih dan dikembangkan kemampuannya. Pada kenyataannya sumber daya manusia dalam perusahaan atau organisasi merupakan suatu wadah untuk mewujudkan pencapaian target dan tujuan perusahaan.

Mengelola karyawan yang memiliki kinerja yang kurang sesuai dengan tingkat yang diharapkan perusahaan bukan merupakan hal yang mudah bahkan untuk seorang supervisor yang berpengalaman sekalipun tidak luput dari pantauan manajemen. Tidak seorang pun yang suka melakukan percakapan yang sulit pada stafnya ataupun kehilangan waktu yang berharga dengan menggunakan sumber daya untuk fokus pada manajemen mikro terhadap karyawan yang memiliki kinerja dibawah standar.

Perusahaan pelayaran PT. Ansari Shipping Batam sangat mementingkan sumber daya manusia yang berkualitas dan profesional terlebih lagi di bidangnya untuk meningkatkan pelayanan dan pendapatan suatu perusahaan pelayaran dalam melaksanakan kegiatan di lapangan ataupun di pelabuhan, agar terwujudnya kesejahteraaan, disamping itu perusahaan pelayaran juga harus menyediakan alat angkut yang berupa kapal termasuk segala fasilitasnya yang diperlukan karena itu juga merupakan faktor pendukung dalam suatu kelancaran suatu kegiatan perusahaan.

Berikut ini rincian proses kedatangan kapal:

Sebelum kapal memasuki wilayah perairan suatu daerah pelabuhan dua hari sebelum pihak kapal (nakhoda) mengirimkan email pada perusahaan pelayran atau agennya di pelabuhan tujuan yang berisikan tentang: nama kapal, perkiraan waktu kedatangan kapal dengan melampirkan copy manifest dan copy loading list, serta mengenai kedatangan kapal di perairan pelabuhan secara pasti pada hari, tanggal serta jenis muatan dan jumlah muatan yang diangkut oleh kapal tersebut.

Jika email telah dikirimkan kepada agen yang ditunjuk oleh pemilik kapal (ship owner) yang mengurus kapal tersebut dan setelah agen yang ditunjuk mendapat SPK (surat penunjukan keagenan) selanjutnya perusahaan pelayaran mengajukan dokumen 1A yang berisikan permohonan fasilitas yang meliputi permohonan untuk labuh, permohonan tambat didermaga, permohonan pandu dan tunda, dan permohonan penggunaan air tawar dengan dilampirkan: copy surat ukur kapal, copy SIB (Surat Izin Berlayar), copy manifest, dan copy dangerous goods manifestor stowage plan (khusus muatan berbahaya). Pihak agen akan mengadakan koordinasi dengan pihak PBM (Perusahaan Bongkar Muat), dan EMKL (Ekspedisi Muatan Kapal Laut) termasuk consignee atau pemilik barang.

Sebelum kapal tiba agen mempersiapkan segala bentuk dokumen kapal untuk sandar di pelabuhan meliputi: menyiapkan dokumen RKSP (Rencana Kedatangan Sarana Pengangkut), dokumen inward manifest beserta dokumen lainnya. Setelah kapal sandar di dermaga maka pihak agen langsung melakukan boarding kapal (mengambil dokumendokumen kapal) untuk proses clearance in kapal.

\section{METODE PENELITIAN}


Dalam memperoleh data yang dibutuhkan sebagai bahan penyusunan laporan tugas akhir, penulis menggunakan metode guna mempermudah penulisan laporan tugas akhir dan agar dapat dipahami serta dimengerti oleh pembaca. Adapun metode yang digunakan penulis guna dalam penulisan ini adalah sebagai berikut:

1.Metode Pengamatan (Observasi)

Dalam metode ini penulis langsung menghimpun data dengan cara langsung mengadakan pengamatan terhadap suatu objek sambil mengamati dan mencatat segala hal yang sudah diamati.

2.Metode Wawancara (Interview)

Teknik pengumpulan data dengan melakukan tanya jawab atau penelitian yang di lakukan secara lisan langsung informasi dan keterangan -keterangan dari senior dan karyawan-karyawan perusahaan di PT. Ansari Shipping Batam.

3.Metode Penelitian Kepustakaan (Library Research)

Metode ini dilakukan melalui perpustakaan untuk mendapatkan data sekunder yang bersumber dari buku pendukung yang menunjang penelitian penulis dalam menyelesaikan tulisan tersebut.

\section{HASIL DAN PEMBAHASAN}

\section{A.Sejarah Singkat Perusahaan}

PT. Ansari Shipping Batam didirikan pada tanggal 02 November 2011 di Batam berdasarkan surat Dirjen Perla, dan akta pendirian perusahaan oleh Notaris dengan No: 17 tanggal 22 Juli 2013, Surat Ijin Usaha Perusahaan Pelayaran (SIUPAL) dengan No. B. XXV - 1705/AL 58, yang mempunyai NPWP: $\quad$ 03.069.079.5.215.000 beralamat di Kompleks Ruko Seraya Mas Center Blok H No 10, Telephone : (0778) 452452, Fax : (0778) 457457.

PT. Ansari Shipping Batam merupakan perusahaan pelayaran yang bergerak pada pelayanan jasa kapal dan barang di Pelabuhan Batam, dimana PT. Ansari Shipping memberikan pelayanan jasa kapal dan barang baik dalam negeri maupun luar negeri, maka PT. Ansari Shipping selalu menjalin hubungan baik pada tiap-tiap instansi terkait. Dalam memberikan pelayanan jasa kapal dan barang demi mencapai suatu pelayanan jasa yang prima dan tepat waktu.Dengan adanya hubungan baik terhadap instansi yang terkait dalam pelayanan jasa tersebut, sangat membantu dalam kelancaran pelayanan jasa kapaldan barang dengan demikian akan memepercepat pertumbuhan ekonomi perusahaan.
B.Gambaran Sumber Daya Manusia Pada PT. Ansari Shipping Batam

\section{Kekuatan Potensi Sumber Daya Manusia Saat} Ini pada Perusahaan PT. Ansari Shipping Batam

Sesuai dengan visi dan misi Perusahaan Pelayaran PT. Ansari Shipping Batam yaitu, dengan visi terwujudnya pelayanan yang prima "customer satisfaction" kepada pengguna jasa, dan dengan misi mengusahakan pelayanan tepat waktu guna memperkecil komplain dari pengguna jasa dan mengoptimalkan estimasi kepada pengguna jasa.

Dalam memberikan pelayanan kepada pengguna jasa maka perusahaan PT. Ansari Shipping Batam menetapkan sumber daya manusia dalam berbagai posisi maka pengarahaan pimpinan pada organisasi dapat berjalan dengan baik untuk pencaapaian tujuan perusahaan.

\section{Analisa}

Berhubungan sumber daya manusia memegang peranan penting dalam suatu perusahaan, maka pada setiap organisasi atau perusahaan diperlukan sumber daya manusia yang berkualitas dan berkompeten untuk menggerakan roda organisasi perusahaan, sehingga perusahaan harus mempertimbangkan dalam merekrut sumber daya manusia yang dapat dimanfaatkan secara tepat guna dan berhasil guna untuk dapat merekrut sumber daya manusia berkualitas dan sesuai kualifikasi pendidikan, diperlukan adanya pengelolaan atau manajemen sumber daya manusia dalam bentuk strategi dan pemanfaatan sumber daya manusia.

Analisa kegiatan selama saya PRADA pada PT. Ansari Shipping Batam pada bulan Maret hingga November 2018 sebagai berikut. Dilihat dari tabel diatas jumlah karyawan pada perusahaan PT. Ansari Shipping Batam berjumlah 6 orang termasuk seorang Direktur dan seorang HRD (human resources departement) yang selalu berada dikantor. Sedangkan 4 orang ditugaskan untuk mengurus urusan lapangan untuk pelayanan kapal keluar masuk pelabuhan dan persiapan bahan baku kebutuhan kapal serta pengurusan dokumen kapal.

Jumlah kapal yang dilayani pada Perusahaan PT. Ansari Shipping Batam yaitu, satu kapal milik yang merupakan kapal rutin yang berlayar dari pelabuhan Batu Ampar Batam ke pelabuhan Pasir Gudang Malaysia ( berangkat dari Pelabuhan Batu Ampar jam 05.00 WIB dan sampai di Pasir Gudang Malaysia lebih Kurang jam 09.00 WIB dan kembali lagi ke Pelabuhan Batu Ampar Batam pada jam 13.00 WIB dari Pelabuhan Pasir Gudang Malaysia dan tiba kembali di Pelabuhan Batu Ampar Batam lebih 
kurang jam 17.00 WIB ). Kapal rutin ini berangkat dari Pelabuhan Batu Ampar Batam ke Pelabuhan Pasir Gudang Malaysia dalam satu minggu sebanyak 4 (empat) . Disamping melayani kapal milik Perusahaan PT. Ansari Shipping Batam juga melayani kapal keagenan yang mana dalam satu bulan bisa lebih kurang 5 unit dengan kapal yang berbeda-beda.

Jadi dilihat dari analisa di atas dapat disimpulkan bahwa Perusahaan PT. Ansari Shipping Batam memerlukan perbaikan kinerja dan penambahan sumber daya manusia karena kedudukan sumber daya manusia saat ini bukan hanya sebagai alat produksi tetapi juga sebagai penggerak dan penentu berlansungnya proses produksi dan segala aktivitas organisasi, pada PT. Ansari Shipping Batam sumber daya manusia memiliki andil besar dalam menentukan maju atau mundurnya suatu perusahaan. Karena semua itu kemajuan suatu perusahaan sangat ditentukan pada kualitas dan kapasitas sumber daya manusia dalam perusahaan. Perusahaan sangat memerlukan sumber daya manusia yang berkualitas serta memiliki kapsitas dalam memberikan pelayanan kepada konsumen atau seluruh pengguna jasa dan untuk menggerakan roda organisasi perusahaan PT. Ansari Shipping Batam maka tidak lepas dari peranan sumber daya manusia, karena memajukan perusahaan dengan meningkatkan daya saing perusahaan, maka dari itu diperlukan sumber daya manusia yang mampu memahami bagaimana cara menciptakan metode pelayanan yang prima bagi pelanggan dan kemudian menciptakan inovasi dalam memanfaatkan potensi sumber daya manusia yang ada pada PT. Ansari Shipping Batam.

Manajemen sumber daya manusia adalah sebuah bagian yang terpenting dalam sebuah perusahaan. Sistem manajemen ini mengatur peranan dan hubungan setiap sumber daya manusia di dalam perusahaan secara efektif dan efisien. Dalam sebuah perusahaan peran departemen yang menangani sumber daya manusia sangatlah besar. Pekerjaan departemen ini akan sangat menentukan kualitas masing-masing karyawan dan kesuksesan yang dapat diraih oleh perusahaan dengan sumber daya yang dimilikinya. Dengan begitu tim manajemen sumber daya manusia adalah mereka yang mengatur dan merencanakan segala sesuatu yang berkaitan dengan hak dan kewajiban settiap sumber daya manusia dalam perusahaan.

Dalam hal ini sumber daya manusia harus memiliki kemampuan dan kapabilitas dalam melaksanakan tugasnya, tidak hanya tugas harian saja tetapi juga mampu menciptakan program-program baru dan inovatif dalam perusahaan. Perusahaan dapat menentukan posisi sumber daya manusia sesuai dengan keahlian dalam bidang masing-masing demi menunjang kinerja dan meningkatkan perkembangan perusahaan, yang berorietasi kepada seluruh sumber daya manusia agar bekerja seoptimal mungkin dalam melaksanakan tugas sesuai bidang tugas masingmasing.

Kondisi sumber daya manusia dalam perusahaan sangat dipengaruhi oleh beberapa faktor antara lain :

1.Faktor eksternal

a.Kondisi ekonomi yang stabil

b.Kondisi pelabuhan Batam

c.Pertumbuhan industri dan perdagangan daerah setempat

d.Hubungan dengan pihak lain di luar PT. Ansari Shipping Batam

2.Faktor internal

a.Kemampuan dan skill karyawan

b.Dedikasi dan loyalitas perusahaan

c.Kompetensi sesuai bidang tugas masing-masing

d.Tata kelola perusahaan yang baik

Manajemen perusahaan harus menciptakan sumber daya manusia yang handal dan kualifaid dengan melakukan training, coaching dan motivation pada setiap karyawan agar mampu menjalankan tugas sebagaimana mestinya. Pada PT. Ansari Shipping kemampuan inilah yang menjadi salah satu kunci kemajuan dan keberhasilan dari perusahaan, bahkan daya saing tinggi akan membuat karyawan siap dengan tantangan arys globalisasi dan membuat perusahaan mampu memanfaatkan peluang sebaikbaiknya.

Bentuk-bentuk konstribusi sumber daya manusia pada PT. Ansari Shipping Batam sebagai berikut :

1.Memberikan pendapatan beserta keuntungan perusahaan secara berkesinambungan.

2.Untuk menjalankan roda organisasi sebagai kelangsungan hidup perusahaan.

3.Dapat menjalankan visi dan misi perusahaan yang ingin dicapai.

Dalam jangka panjang, perusahaan melalui manajemen sumber daya manusia akan diarahkan untuk:

1.Memberikan kesempatan pada sumber daya manusia untuk berkembang menjadi pribadi yang berkualitas dan memiliki daya saing tinggi.

2.Memperkuat produk unggulan disetiap unit kerja menuju keunggulan kompetitif dengan 
mengembangkan keterkaitan sistem produksi, distribusi dan pelayanan dalam perusahaan.

Ada beberapa tugas dan wewenang sumber daya manusia pada perusahaan sebagai berikut :

\section{Perencanaan Sumber Daya Manusia}

Pegawai atau karyawan adalah sumber daya yang dimiliki organisasi dan harus dipekerjakan secara efisien, manusiawi dan efektif. Untuk itu organisasi perlu membuat rencana sebaik-baiknya tentang pegawai yang dibutuhkan bagaimana merekrutnya, dimana pegawai tersebut ditempatkan, bagaimana dia akan dibina dan seterusnya. Perusahaan PT. Ansari Shipping Batam sangat berhati-hati dalam merekrut sumber daya manusia yang akan dipekerjakan, seperti yang dapat dilihat sekarang diperusahaan PT. Ansari Shipping Batam memiliki sumber daya manusia yang berkualitas.

\section{Seleksi dan Orientasi Sumber Daya Manusia}

Perekrutan merupakan suatu proses mencari tenaga kerja serta memberikan suatu harapan dari mereka untuk melamar pekerjaan pada perusahaan. Proses penarikan dimulai ketika para pelamar dicari dan berakhir bila lamaran mereka diserahkan ke perusahaan, proses penarikan sangat penting karena kualitas dalam perusahaan tergantung dari kualitas penarikan.

\section{Pengembangan Sumber Daya Manusia}

Pengembangan sumber daya manusia adalah kegiatan yang harus dilakukan oleh perusahaan, agar pengetahuan, kemampuan, dan keterampilan mereka sesuai dengan tuntutan pekerjaan yang mereka lakukan. Sumber daya manusia di PT. Ansari Shipping Batam juga diberi pelatihan-pelatihan serta pengarahan agar lebih terampil lagi dalam melaksanakan tugasnya.

\section{Manajemen Karir}

Manajemen karir adalah proses untuk membuat karyawan dapat memahami dan mengembangkan dengan baik keahlian dan minat karir mereka dapat dimanfaatkan dengan cara yang paling efektif. Dalam perusahaan PT. Ansari Shipping Batam pembagian tugas dibidang masingmasing jelas.

\section{Penilaian Prestasi Kerja (PPK)}

Penilaian prestasi kerja adalah suatu dalam elakukan evaluasi terhadap prestasi kerja para pegawai dengan serengkaian tolak ukur tertentu yang objektif dan berkaitan langsung dengan tugas seseorang serta dilakukan secara berskala. Setiap karyawan yang berprestasi dalam perusahaan PT. Ansari Shipping Batam selalu dikasih bonus atau imbalan sesuai dengan prestasi kerjanya.

6. Kompensasi
Kompensasi adalah pendapatan yang berupa uang, barang langsung, atau tidak langsung diterima karyawan sebagai imbalan atas jasa yang diberikan kepada perusahaan. Pada akhir tahun PT. Ansari Shipping Batam selalu memberikan kompensasi berupa uang kepada seluruh sumber daya manusianya.

Pada PT. Ansari Shipping Batam manajemen sumber daya manusia merupakan moto penggerak penunjang kegiatan manajemen yang harus dimanfaatkan sebaik mungkin melalui sinergi dengan lingkungan, sehingga tidak dipungkiri dengan adanya perubahan teknologi yang sangat pesat, memaksa manajemen PT. Ansari Shipping Batam untuk bisa menyesuaikan diri dengan lingkungan usahanya, karena seiring dengan perkembangan iptek yang semakin pesat otomatis timbulnya pesaing-pesaing yang semakin ketat, maka dari itu sumber daya manusia Perusahaan PT. Ansari Shipping Batam akan bisa menghadapi persaingan global yang semakin maju, dalam arti kata Perusahaan PT. Ansari Shipping Batam mampu menyusun strategi dan kebijakan yang ampuh untuk mengatasi setiap perubahan yang akan terjadi.

Dalam aplikasi strategi manajemen untuk memanfaatkan sumber daya manusia pada PT. Ansari Shipping Batam antara lain sebagai berikut :

1.Penerapan manajemen terbuka, dalam hal ini semua tugas, tanggung jawab, wewenang dan hak serta kewajiban semuanya terbuka dan tidak ada yang ditutupi.

2.Penempatan sumber daya manusia menurut bidang tugasnya masing-masing sesuai kualifikasi pendidikannya.

3.Pemberian kompensasi sesuai hasil kerja yang dilaksanakan dengan memperhatikan azaz efektifitas dan efisiensi.

4.Pemanfaatan tenaga praktek kerja lapangan sekaligus untuk penempatan bibit-bibit yang berbakat dan diharapkan nantinya mampu bergabung dalam tim kerja PT. Ansari Shipping Batam.

5.Pemantauan dan memonitoring secara bertingkat dari atas ke bawah melalui mekanisme pengawasan melekat.

3.Hambatan Dalam Upaya Perbaikan Sumber Daya Manusia dalam Peningkatan Pelayanan Kapal

a.Hambatan Kegiatan Operasional Sebelum Perbaikan Sumber Daya Manusia (SDM)

Ada beberapa kendala sebelum adanya peningkatan kinerja sumber daya manusia yang berbasis kompetensi yang diantaranya sebagai berikut : 
1.Sumber daya manusia bekerja tidak sesuai dengan keahlian, Bila karyawan yang bekerja tidak sesuai dengan bidangnya akan menjadikan kinerja perusahaan menurun atau perusahaan tidak mengalami peningkatan sama sekali.

2.Jabatan Rangkap pada PT. Ansari Shipping Batam, Pada PT. Ansari Shipping Batam terdapat jabatan rangkap hal ini dikarenakan PT. Ansari shipping Batam kekurangan sumber daya manusia. Hal ini akan mengakibatkan perusahaan tidak dapat melakukan kegiatan dengan efektif dan efisien.

3.Tidak adanya pelatihan bagi sumber daya manusia dalam bidang-bidang khusus pada perusahaan PT. Ansari Shipping Batam.

Dengan tidak diberikan pelatihan pada karyawan maka karyawan tersebut tidak bisa bekerja dengan baik karena karyawan hanya bisa bekerja pada satu bidang dalam perusahaan yaitu bidang yang dikerjakan oleh karyawan tersebut, maka efektif dan efisien yang sudah ditetapkan oleh perusahaan belum tercapai dengan baik.

b.Hambatan Kinerja pada Sumber Daya Manusia Terhadap Peningkatan Pelayanan Kapal

Disini akan menjelaskan sedikit gambaran mengenai kinerja sumber daya manusia terhadap peningkatan pelayanan kapal. Dalam Perusahaan PT. Ansari Shipping Batam memiliki jumlah sumber daya manusianya berjumlah 6 orang, dari jumlah sumber daya manusia 6 orang tadi dapat dibagi dalam setiap bidang tugas bisa 2 orang sekaligus dalam satu bidang tugas, dibagian keagenan kapal pada setiap pelabuhan yang berbeda hanya dapat menghandle 1 kapal dalam sehari hal ini dikarenakan jumlah sumber daya manusia dalam PT. Ansari Shipping Batam tidak sesuai dengan jumlah kegiatan dilapangan. Dengan jumlah sumber daya manusia dalam perusahaan tidak seimbang dengan kegiatankegiatan yang ada dalam perusahaan, dan ini sangat mempengaruhi berkurangnya pendapatan dalam perusahaan. Maka dari itu dalam merekrut sumber daya manusia yang akan dipekerjakan dalam perusahaan seharusnya lebih diperhatikan berapa jumlah sumber daya manusia yang dibutuhkan dalam suatu perusahaan, atau dapat merekrut sumber daya manusia dengan harus memperhatikan skill, knowledge dan ability.

4.Upaya Perbaikan Sumber Daya Manusia Untuk peningkatan Pelayanan Kapal

a.Penambahan Jumlah Sumber Daya Manusia

Penambahan jumlah sumber daya manusia bermaksud agar jumlah sumber daya manusia pada
Perusahaan PT. Ansari Shipping Batam sesuai dengan jumlah kegiatan dilapangan agar tercapainya efektif dan efisien dalam melakukan kegiatan dilapangan. Disamping untuk tercapainya efektif dan efisien dalam melaksanakan kegiatan dilapangan, ini bermaksud agar tidak terjadi rangkap jabatan dalam Perusahaan PT. Ansari Shipping Batam. Dengan adanya penambahan jumlah sumber daya manusia maka akan tercapainya tujuan dari perusahaan.

b.Mengadakan Pelatihan Bagi Karyawan

Sebelum karyawan bekerja perlu adanya pelatihan atau training agar karyawan tersebut bisa bekerja dengan baik agar tercapainya eketif dan efisien yang telah ditetapkan perusahaan. Dengan adanya pelatihan atau training maka karywan tersebut bisa mengetahui tidak hanya satu bidang dalam perusahaan tetapi bisa semua bidang dalam perusahaan ini bertujuan agar karyawan bisa melaksanakan kegiatan dalam peruusahaan apabila ada karyawan yang berhalangan untuk melaksanakan tugas pada bidangnya.

c.Pelaksanaan Konsolidasi Kekuatan Sumber Daya Manusia

Kekuatan adalah keadaan positif dalam internal perusahaan yang dapat membantu meningkatkan daya saing perusahaan untuk pengembangan karyawan sebagai sebuah kekuatan diperlukan sebuah proses analisis kebutuhan agar institusi mampu bertahan dalam dunia persaingan yang sangat kompetitif serta mengasilkan kinerja yang benar-benar mampu memberikan kepuasan kepada pelanggan.

Dapat dikatakan bahwa kualitas kerja adalah suatu hasil yang dapat diukur dengan efektifitas dan efisiensi dari suatu pekerjaan yang dilakukan oleh sumber daya manusia dalam pencapaian tujuan atau sasaran perusahaan dengan baik dan berdaya guna.

Beberapa bentuk konsolidasi kekuatan Sumber Daya Manusia (SDM) pada PT. Ansari Shipping Batam yaitu :

a.Kebijakan rekrutment

b.Penempatan skill yang tepat

c.Penyesuaian kompensasi

d.Perencanaan dan pengembangan karir

e.Kesempatan kerja yang sama

Untuk dapat meningkatkan kualitas kerja ada beberapa cara yang dapat dilakukan perusahaan yaitu dengan memberikan pelatihan atau training, memberikan insentive atau bonus dan mengaplikasikan atau menerapkan teknologi yang dapat membantu meningkatkan efisiensi dan efektifitas kerja. 
Setiap sumber daya manusia yang melakukan tugasnya pada bidang tertentu sesuai job discription, baik terhadap peningkatan kinerja sumber daya manusia, maupun pada bidang lain yang berkaitan dengan perusahaan adalah bertujuan untuk kemajuan perusahaan tersebut.

Dari hasil konsilidasi dari peningkatan kinerja sumber daya manusia pada PT. Ansari Shipping Batam dapat dilihat sebagai berikut :

1.Penetapan balas jasa

Penetapan balas jasa adalah imbalan yang diberikan kepada karyawan atas jasa dan prestasi yang telah diberikan untuk perusahaan.

2.Upah

Upah adalah penerimaan sebagai suatu imbalan dari pemberi kerja kepada penerima kerja untuk suatu pekerjaan yang akan dilakukan, berfungsi sebagai jaminan kelangsungan kehidupan yang layak bagi kemanusiaan dan produksi, dan dinyatakan atau dinilai dalam bentuk uang yang ditetapkan menurut suatu persetujuan UU dan peraturan-peraturan dan dibayarkan atas dasar suatu perjanjian kerja.

3.Insentif

Insentif adalah pengupahan yang memberikan imbalan yang berbeda karena memang prestasi yang berbeda.

4.Kompensasi

Kompensasi adalah pemberian imbalan jasa yang layak dan adil kepada karyawan-karyawan karena mereka telah memberikan sumbangan kepada pencapaian organisasi.

\section{KESIMPULAN}

1.Sumber daya manusia sangat berperan penting dalam mencapai tujuan suatu organisasi, tanpa adanya sumber daya manusia maka PT. Ansari Shipping Batam tidak akan berjalan seperti sekarang.

2.Sumber daya manusia rangkap jabatan akan berpengaruh pada kinerja karyawan, ini akan mengakibatkan kegiatan dilapangan tidak efektif dan efisien pada Perusahaan PT. Ansari Shipping Batam dan tidak adanya pelatihan yang diberikan kepada karyawan maka karyawan tersebut tidak bisa bekerja dengan baik karena karyawan hanya bisa bekerja pada satu bidang dalam perusahaan yaitu bidang yang dikerjakan oleh karyawan tersebut, maka efektif dan efisien yang sudah ditetapkan oleh perusahaan belum tercapai dengan baik

\section{DAFTAR PUSTAKA}

Kosasih, Engkos. Manajemen Perusahaan Pelayaran. Jakarta : Rajawali Pers, 2009.

Rivai, Manajemen Sumber Daya Manusia Dalam Organisasi. Jakarta : PT. Pustaka Gramedia Utama, 2004.

Hasibuan, Melayu. Manajemen Sumber Daya Manusia. Jakarta : Bumi Aksara. 2007.

Sir, Jacob. 2008. Operasi Terminal dan Kepelabuhanan dan Manajemen Perusahaan Pelayaran. Medan. Akademi Maritim Indonesia Medan. 